УДК 621. 924.9

(C) 2016

Горик О. В., доктор технічних наук,

Брикун О. М., асистент

Полтавська державна аграрна академія

Черняк Р. С., інженер

Публічне акціонерне товариство «АвтоКрАЗ»

\title{
ВИБІР ОПТИМАЛЬНИХ ПАРАМЕТРІВ ТЕХНОЛОГІЇ ДРОБЕСТРУМЕНЕВОӤ ОБРОБКИ ВНУТРІШНІХ ПОВЕРХОНЬ ВЕЛИКОГАБАРИТНИХ ЕЛЕМЕНТІВ АВТОМОБІЛЬНОЇ ТЕХНІКИ
}

\section{Рецензент - доктор технічних наук А. А. Смердов}

\begin{abstract}
На основі результатів останніх відомих досліджень теорії ударної взаємодії твердих частинок (дробинок) з пружно-пластичним півпростором стосовно дробеструменевої очистки порожнин цииліндричних ємкостей, типу тіл обертання, узагальнено технологічні критерії такого процесу, як вихідні дані для створення технічних засобів автоматизації підготовки поверхонь до покриття неметалевим захисним шаром, подано підходи до визначення основних характеристик руху відбитку абразивного факела по оброблюваній криволінійній внутрішній поверхні виробу за умови рівномірного і якісного очищення.
\end{abstract}

Ключові слова: дробеструменеве очищення, порожнини цуиліндричних ємностей, технологічні режими, автоматичний маніпулятор, абразивний факел, траєкторія руху.

Постановка проблеми. Механізація процесу очищення внутрішньої поверхні великогабаритних циліндричних ємностей є одним із найважчих завдань сільськогосподарського та транспортного машинобудування, яке, не дивлячись на неодноразові спроби, не вдалося вирішити впродовж останніх 50 років. Подібні завдання не вирішені також на машинобудівних заводах, що виготовляють ядерні реактори, нафтоналивні цистерни, хімічні та біологічні апарати.

До теперішнього часу цю трудомістку і шкідливу для здоров'я людини операцію виконують, переважно, ручним способом. Із механічних способів очищення поверхні металевих виробів від механічних і окисних забруднень перед нанесенням захисних неметалевих покриттів отримало дробеструменеве очищення (ДО) [6]. Особливо ефективним виявляється застосування ДО для порожнин великогабаритних металевих виробів, де інші способи механічної обробки є малопридатні. Це пояснюється технологічною гнучкістю, екологічною безпекою, високою продуктивністю, експлуатаційною надійністю і еконо- мічною ефективністю ДО. Але широке застосування цього процесу стримується не досконалою конструкцією засобів механізації і автоматизації, які не відповідають сучасним вимогам у силу не повної узгодженості технологічних основ під час розробки відповідних технічних рішень [2]. Ці проблеми потребують постійної уваги дослідників.

Аналіз останніх досліджень і публікацій, у яких започатковано розв'язання проблеми. Глибокий аналіз методів і засобів механізації струменево-абразивної обробки поверхонь приведений у [1], де подано перелік останніх патентів на винаходи різноманітних пристроїв, пов'язаних 3 обробкою металевих поверхонь. Але вони практично не висвітлюють технологію i автоматизацію процесу очистки внутрішніх поверхонь порожнистих ємностей. Що стосується очистки внутрішніх поверхонь великогабаритних кругових циліндричних виробів, то тут слід відмітити роботи $[2,4,7]$, які висвітлюють засоби автоматизації, але без належного узгодження 3 технологічними основами процесу очищення. У [8], навпаки, технологічна карта очищення порожнин потребує ув'язки із технічними рішеннями засобів механізаціі.

Мета дослідження - аналітичне узгодження технологічних параметрів 3 технічними рішеннями на засоби механізації процесу ДО внутрішньої поверхні корпусів біологічних апаратів для удосконалення методів автоматизації струменевоабразивної обробки порожнин.

Завданням є узагальнення технологічних $\mathrm{i}$ технічних показників процесу очистки абразивними факелами металевих поверхонь та використання цих показників під час розробки технічного рішення автоматичного маніпулятора.

Методом дослідження $\epsilon$ побудовані моделі ударної взаємодії твердих частинок (дробу) 3 
пружно-пластичним півпростором, статистична оцінка відомих і отриманих експериментальноаналітичних даних стосовно ДО.

Результати досліджень. Узагальнимо основні параметри ДО, як вихідні дані для встановлення технологічних критеріїв автоматизації процесу, який полягає в механічній обробці вільними абразивними зернами (дробинками) оброблюваної поверхні під певним кутом і швидкістю (рис. 1). Водночас відбувається масове швидкісне знімання елементарних об'ємів матеріалу [5].

Повітряно-абразивна суміш формується циліндричним соплом 1 з робочим діаметром $d_{c}, 3$ якого суміш вилітає у вигляді конічного факелу 23 кутом розкриття $2 \alpha$, і атакує оброблювану поверхню 3. Діаметр сопла становить $d_{c}=6 . .12 \mathrm{Mm}$ залежно від діаметра дробу $d_{\partial p}$. Найбільші швидкості $v_{0}=150 \ldots 180 \mathrm{~m} / \mathrm{c}$ дробинки досягають на відстані $l_{0} \approx 10$ мм від зрізу сопла після повного вирівнювання тиску стислого повітря 3 тиском навколишнього середовища. Далі швидкість дробинок падає по експоненціальному закону.

На практиці дотримуються відстані від сопла до оброблюваної поверхні $l \approx 0,2 \ldots 0,5$. Не дивлячись на зменшення початкової швидкості дробинок $v_{0}$ приблизно на 20-50 \%, це дає можливість оптимально витрачати енергію стислого повітря, максимально охоплювати оброблювану поверхню i ефективно використовувати ріжучі властивості дробинок.

Для виготовлення дробу використовують сталь, чавун, скло та інші матеріали, які відповідають хімічному складу металевої основи або захисного покриття, і водночас мають достатньо високу міцність і твердість (HRC 45-50 по Роквеллу). Найбільшу технологічну продуктивність очищення $6 \ldots 12 \mathrm{~m}^{2} /$ год залежно від ступеня забруднення оброблюваної поверхні дає сталева дріб фракції № 1 , тобто $d_{\partial p}=1$ мм .

Для міцного зчеплення грунту захисного покриття 3 металевою основою остання повинна бути якісно очищена 3 утворенням рівномірної шорсткості [5]. Для цього з поверхні деталі знімається шар завтовшки $\delta_{n p}$.

Сопло 3 матеріальним отвором діаметром $d_{c}=10$ мм викидає дріб діаметром 1мм 3 масовою подачею $q=25 . . .30 \kappa 2 / x в$ при робочому тиску енергоносія в корпусі дробеструменевого апарату $p=0,5 \ldots 0,6 M \Pi a$, забезпечуючи технологічну об'ємну продуктивність $Q_{o}=(0,5 \ldots 1) \cdot 10^{-4} \mathrm{M}^{3} / x_{8}$ і поверхневу продуктивність $Q_{\text {пов }}=0,1 \ldots 0,2 \mathrm{~m}^{2} / x_{8}$ за глибини обробки $\delta_{n p}=0,5 м \mu$.

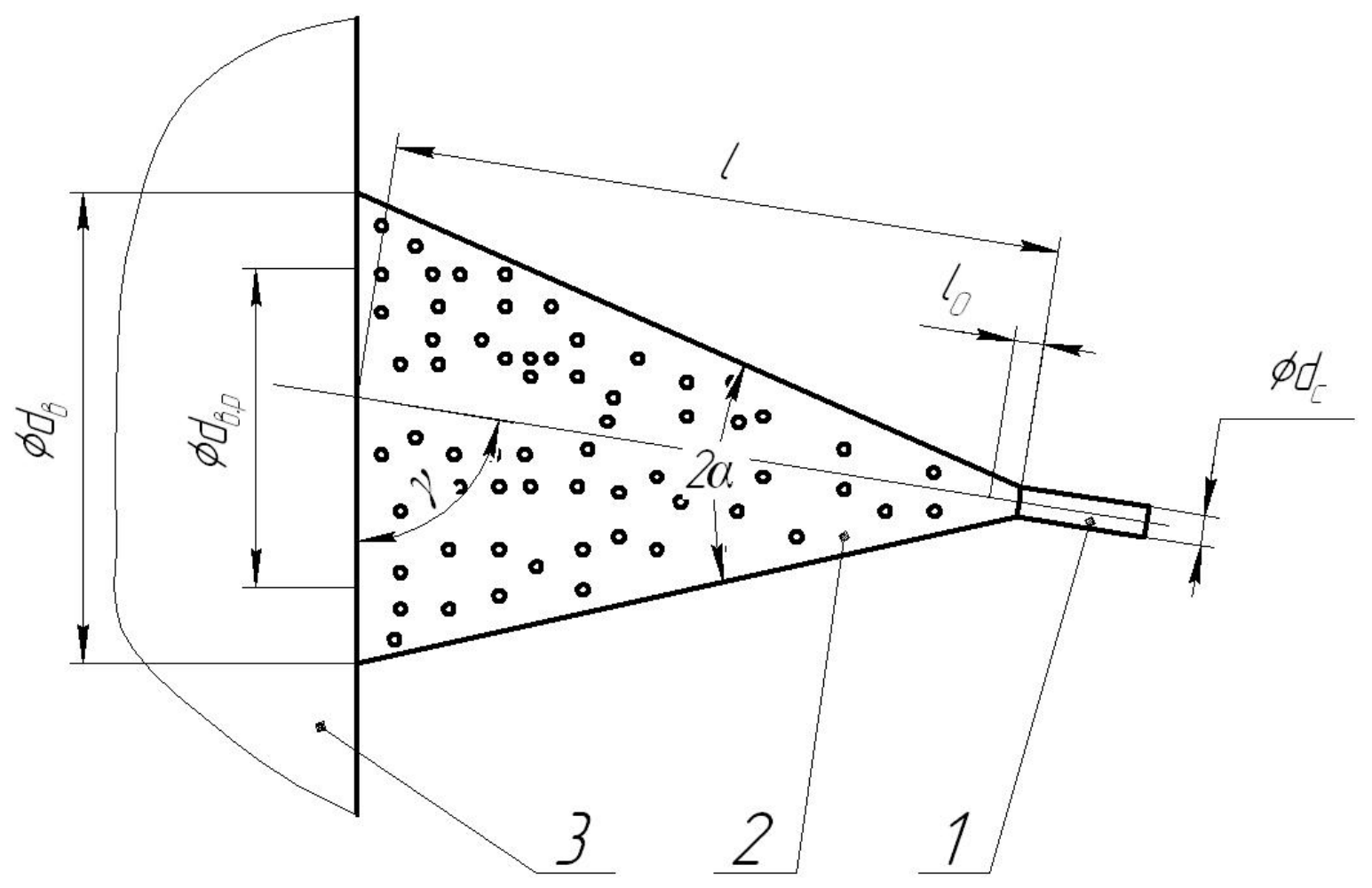

Рис. 1. Схема абразивного факелу 
За реального діаметру відбитку факела на поверхні $d_{\text {s.p }} \approx 0,1_{\mathcal{M}}$ така продуктивність досягається у випадку швидкості переміщення відбитку по відношенню до оброблюваної поверхні $v_{\phi}=1 \ldots 2 \mathrm{M} / \mathrm{x}_{\boldsymbol{B}}$.

Середня арифметична висота мікронерівностей оброблюваної поверхні $R_{a}$ залежить від фракційного складу абразивних частинок $d_{\partial p} \mathrm{i}$ встановлюється по співвідношенню: $R_{a} \approx 0,1 d_{\partial p}$.

Для надійного зчеплення грунту захисного покриття 3 металевою основою, товщина якого становить $\delta_{z p} \approx 500$ мкм, необхідно мати певну шорсткість металевої поверхні, а саме $R_{a} \approx(0,2 \ldots 0,25) \delta_{z p} \approx 80 \ldots 100$ мкм. Таку шорсткість можна отримати у разі діаметру абразивних частинок $d_{\partial p}=0,8 \ldots 1,0$ мм , яка відповідає також і умові найвищої продуктивності. Для досягнення оптимальних критеріїв процесу очищення кут атаки $\gamma$ дробинок для маловуглецевої сталі 10 повинен становити $35^{\circ} . .60^{\circ}$ [3].

Для здійснення процесу ДО поверхні металевих виробів різної конфігурації можливі довільні траєкторії переміщення відбитку факела по оброблюваній поверхні за дотримання вимоги відбиток не повинен двічі проходити одну й ту ж поверхню.

Для механізації процесу ДО траєкторія руху відбитку факела по оброблюваній поверхні набуває вирішального значення. Вона повинна бути впорядкованою і достатньо простою.

Від складності траєкторії залежить реальність створення виконавчого механізму.
Такі узагальнені параметри процесу ДО використовуємо для створення технологічної карти очищення порожнини суцільнозварної циліндричної ємності (рис. 2), яка складається з циліндричної обичайки 1 з радіусом $R$ і днищ: переднього 2 з відкритим люком із радіусом $r_{\pi}$ та заднього (тильного) 3 з вихідним патрубком із радіусом $r_{1}$ або без нього.

Кузовні елементи автомобільної техніки, корпуси біологічних (хімічних) апаратів виконуються у вигляді тіл обертання, утворюючими яких є еліптичні і прямі лінії [8].

Тому можна дійти до висновку, що найбільш відповідними траєкторіями переміщення відбитку факела по оброблюваній поверхні будуть розімкнені криві з постійним кроком, якими є гвинтова спіраль для обичайки і спіраль Архімеда для днищ (рис. 2).

Відповідно до таких вимог нами у $[4,7]$ запропоновано автоматичний маніпулятор, який забезпечує рух подачі відбитка факела, починаючи від вихідного патрубка тильного днища $3, \mathrm{i}$ далі рух відбувається по твірній еліптичної кривої тильного днища, переходить на твірну пряму циліндричної обичайки 1 і потім по твірній еліптичної кривої переднього днища 2 досягає відкритого люка.

На цьому ДО порожнини виробу закінчується.

Технологічні можливості такого маніпулятора узгоджуються з наступними параметрами автоматизації процесу ДО порожнин габаритних циліндричних ємностей.

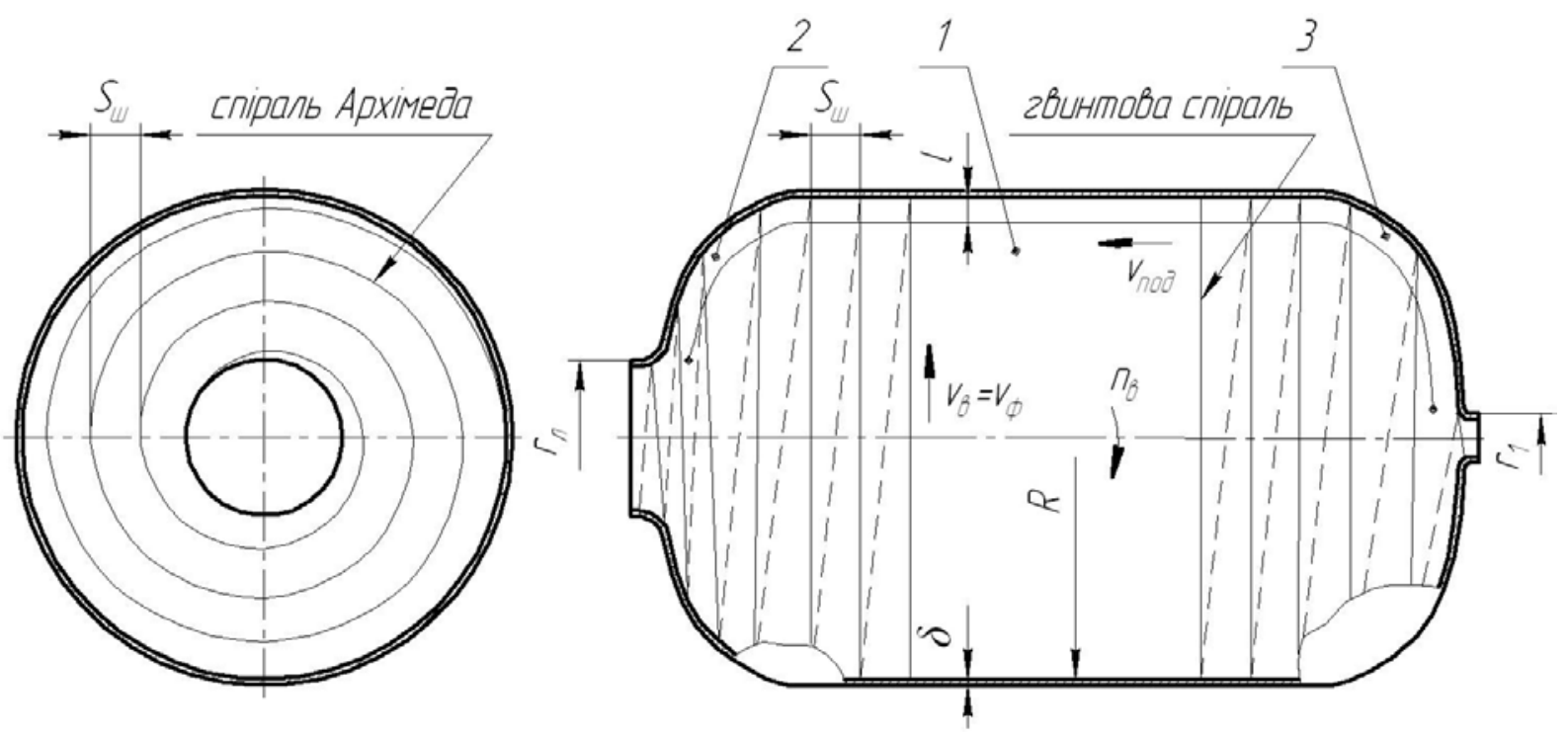

Рис. 2. Технологічна схема ДО порожнини циліндричної ємності 


\section{TЕХНІЧНI НАУКИ}

За умови безпечної роботи оброблюваний виріб повинен обертатися з лінійною швидкістю обичайки $v_{\varepsilon}<10 M / x \beta$. Тоді частота обертання ємності за радіусу $r$ руху відбитку факела становитиме:

$$
n_{B}=v_{B} /(2 \pi r) \leq 10 /(2 \pi r) .
$$

Рівномірної обробки поверхні виробу типу тіла обертання можна досягти за умови, коли відбиток факела 3 діаметром $d_{\beta}$ рухатиметься зі швидкістю $v_{\phi}=1 \ldots 2 \mathrm{M} / x_{8}$ по розімкненій спіралі, крок якої $S_{u}$ не повинен бути більше реального діаметру відбитку факела $d_{s . p}=0,8 d_{s}=1,6 \mathrm{ltg} \gamma$, тобто, $S_{u} \leq 1,6 \operatorname{ltg} \gamma$, і одночасно по утворюючій кривій із швидкістю подачі $v_{\text {под }}$, яка забезпечує необхідне перекриття факелом оброблюваної поверхні.

3 огляду на те, що кругова швидкість $v_{в}$ виробу прямо пропорційна радіусу $r$ руху відбитка факелу і частоті $n_{6}$ обертання виробу, то для складових частин корпусу оброблюваного виробу - еліптичних днищ і циліндричної обичайки частота обертання виробу буде змінюватися за дотримання вимоги:

$$
v_{\phi}=v_{B}=2 \pi r n_{B}=\text { const } .
$$

Тож, у разі зміни радіуса руху відбитку факела необхідно змінювати і частоту обертання виробу навколо власної вісі, яка (вісь) визначає швидкість переміщення відбитку дробеструменевого факела під час очищення окремих складових корпусу апарату.

Так, для тильного еліптичного днища, яке має вихідний патрубок радіусом $r_{1}$, частота обертання (1) буде змінною: за початкового радіусу обробки $r_{n}^{m}=r_{1}$ і кінцевого радіусу (радіусу обичайки $R$ ) $r_{\kappa}^{m}=r_{\kappa}=R$, а саме:

$$
\begin{gathered}
n_{n}^{m}=v_{\text {o }} /\left(2 \pi r_{1}\right), \\
n_{\kappa}^{m}=v_{в} /\left(2 \pi r_{\kappa}\right)=v_{b} /(2 \pi R) .
\end{gathered}
$$

Під час очищення обичайки корпус повинен обертатися $з$ постійною частотою

\section{БІБЛІОГРАФІЯ}

1. Андилахай A. А. Анализ струйно-абразивных методов обработки поверхностей / А. А. Андилахай // Сборник научных трудов «Вестник НТУ "ХПИ"» : Технології в машинобудуванні. - 2010. №53. - С. 4-10.

2. Визначення оптимальних технологічних

$$
n=v_{в} /(2 \pi R) .
$$

Для переднього днища, яке має центральний люк з радіусом $r_{л}$, у разі початкового радіусу очищення $r_{n}^{n}=R$ і кінцевого радіусу обробки $r_{\kappa}^{n}=r_{\pi}$

$$
n_{n}^{n}=v_{в} /(2 \pi R), \quad n_{\kappa}^{n}=v_{в} /\left(2 \pi r_{л}\right) .
$$

Відповідно до прийнятої схеми руху відбитка факела по оброблюваній поверхні «тильне днище - обичайка - переднє днище» подача відбитка факела $v_{\text {под }}$ уздовж твірної порожнини корпусу буде змінюватися за законом

$$
v_{\text {nод }}=S_{u} / t=S_{u} v_{\phi} /(2 \pi R),
$$

де $t$ - час пересування факела з одного витка на інший, хвилин.

3 огляду на те, що для рівномірного очищення частота обертання виробу не повинна бути менше максимальної частоти обертання корпусу під час обробки з найменшим радіусом $r_{1}$ вихідного патрубка, частоту обертання виробу $n=n_{6}$ приймаємо рівною і постійною

$$
n_{\text {в }}=n_{n}^{m} \text {. }
$$

Якщо допустима частота обертання виробу (1) не може забезпечити необхідну швидкість переміщення відбитку факела, то головний рух повинен здійснювати інструмент. А додаткове обертання виробу з безпечною частотою дасть змогу більш рівномірно обробляти поверхню і використовувати галтовку поверхні відпрацьованим дробом, який знаходиться в порожнині виробу.

Висновок. Результати узагальнення технічних показників дробеструменевого очищення внутрішньої поверхні циліндричних кузовних ємностей під захисне неметалеве покриття, як вихідних параметрів, дасть змогу створювати оптимальні конструкції автоматичних маніпуляторів для виконання трудомісткої і шкідливої для здоров'я людини операції абразивної підготовки поверхонь виробів типу тіл обертання і таким чином значно підвищити рівень автоматизації цього процесу.

режимів дробеструменевого очищення металевих поверхонь / [Горик О.В., Чернявський А. М., Ландар А. А., Шулянський Г. А.]. - Полтава : ПДАА, 2012. - $100 \mathrm{c.}$

3. Горик О. В. Динаміка та міцність енергетичних і сільськогосподарських машин та біотехні- 


\section{ТЕХНІЧНІ НАУКИ}

чних систем : колективна монографія / О. В. Горик, С. Б. Ковальчук. - Полтава : Видавництво «Сімон», 2015. - С. 77-84.

4. Патент на винахід №105279. Маніпулятор дробеструменевого очищення / [Горик О. В., Чернявський А. М., Ландар А. А., Шулянський Г. А.]. № a 201210574 ; заявл. 07.09.2012 ; опубл. 25.04.2014, Бюл. №8.

5. Смирнов Н. С. Очистка поверхности стали / Н. С. Смирнов, М. Е. Простаков, Я. Н. Липкин. М. : Металлургия, 1978. - 232 с.

6. Спринг С. А. Очистка поверхности металлов / С. А. Спринг. - М. : Мир, 1966. - 349 с.
7. Шулянський $Г$. А. Автоматизація технологічного процесу дробеструменевого очищення сільськогосподарських резервуарів / Г.А.Шулянський, О. М. Брикун // Динаміка та міцність енергетичних i сільськогосподарських машин та біотехнічних систем. - Полтава : видавництво «Сімон», 2015. - С. 84-87.

8. Шулянський Г.А. Визначення параметрів пересування відбитку дробеструменевого факелу при очистці порожнин виробів // Галузеве машинобудування, будівництво : зб. наук. праць. Полтава : ПДТУ, 2012. - Вип.2 (32). - Том 2. C. $122-127$. 